\title{
Retraction: Isolation of curcumol from zedoary turmeric oil and its inhibitory effect on growth of human hepatocellular carcinoma xenografts in nude mice
}

The editorial board of Food Science and Technology, announces the formal retraction of the following article:

- Tian, Y., Pang, X., \& Wang, F. (2022). Isolation of curcumol from zedoary turmeric oil and its inhibitory effect on growth of human hepatocellular carcinoma xenografts in nude mice. Food Sci. Technol, Campinas, 42, e46621. https://doi.org/10.1590/ fst. 46621

This decision was made based on the fact that the article has a serious mistake in the contents. In preparing the work, due to author's honest mistake, the data of thymus index were placed in the text. These data should be removed.

Prof. Dr. Adriano Gomes da Cruz

Editor-in-chief 


\title{
Isolation of curcumol from zedoary turmeric oil and its inhibitory effect on growth of human hepatocellular carcinoma xenografts in nude mice
}

\author{
Yuan TIAN ${ }^{1,2,3,4 *}$, Xin PANG ${ }^{1,2,3,4 \#}$, Fengmei WANG ${ }^{2,3,4,5 *}$ (D)
}

\begin{abstract}
This study investigated the inhibitory effect and mechanism of curcumol on growth of human hepatocellular carcinoma (HCC) HepG2 xenografts in nude mice. Curcumol was isolated from from zedoary turmeric oil. The HepG2 xenograft model in nude mice was established. Forty modeled nude mice were divided into model, cisplatin, curcumol and cisplatin+curcumol groups. The latter three groups were treated with $2 \mathrm{mg} / \mathrm{kg}$ cisplatin, $100 \mathrm{mg} / \mathrm{kg}$ curcumol and $2 \mathrm{mg} / \mathrm{kg}$ cisplatin combined with 100 $\mathrm{mg} / \mathrm{kg}$ curcumol, respectively, once every two days, for total seven times. After treatment, compared with cisplatin group, in cisplatin+curcumol group the tumor weight and tumor inhibition rate were obviously increased, the apoptosis rate of HepG2 cells was obviously increased, the expression levels of Caspase-3 and B-cell lymphoma-2 associated X proteins in xenograft tumor were significantly increased, and the expression level of B-cell lymphoma-2 protein was significantly decreased. In addition, the thymus index and spleen index of animal had no significant difference between cisplatin group and cisplatin+curcumol group. In conclusion, the additional use of curcumol can obviously increase the inhibitory effect of cisplatin on growth of HCC HepG2 xenografts in nude mice. The mechanism may be related to the enhanced promotion of apoptosis of tumor.
\end{abstract}

Keywords: curcumol; hepatocellular carcinoma; HepG2; xenografts; apoptosis.

Practical Application: This study has provided an experimental basis for the clinical application of curcumol to cancer therapy.

\section{Introduction}

Hepatocellular carcinoma (HCC) is one of the most common malignant tumors. It has the characteristics of occult onset, rapid progress, high malignancy, short survival, difficult treatment and poor prognosis (Tangkijvanich et al., 2000). Chemotherapy is one of the main methods for the treatment of HCC. However, the traditional chemotherapy drugs can kill the cancer cells, and also damage the normal cells in different degrees, which seriously affects the patients' compliance and treatment effect. HCC is generally resistant and insensitive to chemotherapy drugs (Thomas, 2009). With the progress of molecular biology and chemical separation technology, the experimental study of natural drugs in the treatment of HCC has become a research hotspot of tumor therapy (Wu \& Xie, 2008; Rawat et al., 2018).

Studies have found that many plants contain the ingredients which have good activities in antioxidant, anti-inflammatory, anti-tumor and other aspects (Costa et al., 2020; Huang et al., 2020; Santos et al., 2021). Curcumol is a sesquiterpene compound isolated from the zedoary turmeric oil which has long been used as a folk medicine in China for many years (You et al., 2005). Its molecular formula is $\mathrm{C}_{15} \mathrm{H}_{24} \mathrm{O}_{2}$, with molecular weight of 236.35. The pharmacological studies show that curcumol has the anti-inflammatory, anti-oxidation and anti-tumor effects (Tsai et al., 2011; Chen et al., 2014; Wang et al., 2015). Curcumol plays an anti-tumor role by inhibiting tumor cell proliferation, promoting tumor cell apoptosis and inhibiting the angiogenesis (Liu et al., 2019). At present, most of the studies on the antitumor effect of curcumol are focused on the in vitro experiments, and the results of animal experiments are few (Tang et al., 2015). It is found that curcumol can inhibit the proliferation of HCC HepG2 cells (Huang et al., 2013). In this study, curcumol was isolated from from zedoary turmeric oil, and the inhibitory effect and mechanism of curcumol on growth of human HCC HepG2 xenografts in nude mice were investigated. The objective was to provide an experimental basis for the clinical application of curcumol to cancer therapy.

\section{Materials and methods}

\subsection{Isolation of curcumol from zedoary turmeric oil}

A $50 \mathrm{ml}$ of zedoary turmeric oil was placed in a round bottom flask, followed by vacuum distillation in oil bath. The $208-216^{\circ} \mathrm{C}$ fractions were collect. The fractions were washed with petroleum ether for several times. After drying, the recrystallization with absolute ethanol was performed. Finally, the white crystals were obtained, which were the curcumol product. The purity of curcumol was $89.03 \%$. 


\subsection{Culture of HepG2 cells}

HepG2 cells (Cell Bank of the Chinese Academy of Sciences, Shanghai, China) were cultured with RPMI 1640 medium containing $10 \%$ calf serum, $100 \mathrm{U} / \mathrm{ml}$ penicillin and $100 \mathrm{U} / \mathrm{ml}$ streptomycin at $37^{\circ} \mathrm{C}$ and with $5 \% \mathrm{CO}^{2}$. The cells were digested and passaged using $0.25 \%$ trypsin, and the medium was changed once every three days.

\subsection{Establishment of HepG2 xenograft model in nude mice}

The HepG2 cells in logarithmic growth phase were taken, and the concentration of cells was adjusted to $5 \times 10^{6}$ cells $/ \mathrm{ml}$. A $0.5 \mathrm{~mL}$ of cell fluid was taken, and injected subcutaneously into the right lower limb of nude mice (BALB/c; male; 4-6 weeks old; 18-22 g). About one week later, the appearance of xenograft tumor with diameter more than $4 \mathrm{~mm}$ presented the successful establishment of HepG2 xenograft model.

\subsection{Treatment methods}

As show in Figure 1, forty successfully modeled nude mice were divided into the model group, cisplatin group, curcumol group and cisplatin+curcumol group, 10 nude mice in each group. The nude mice in model group were intraperitoneally injected with $0.2 \mathrm{~mL}$ of normal saline. The cisplatin group was intraperitoneally injected with $2 \mathrm{mg} / \mathrm{kg}$ cisplatin. The curcumol group was intraperitoneally injected with $100 \mathrm{mg} / \mathrm{kg}$ curcumol. The cisplatin+curcumol group was intraperitoneally injected with $2 \mathrm{mg} / \mathrm{kg}$ cisplatin combined with $100 \mathrm{mg} / \mathrm{kg}$ curcum 1 . The injection was performed once every two days, for total seven times. During the treatment, the survival state of nude mice and the xenograft tumor growth were observed.

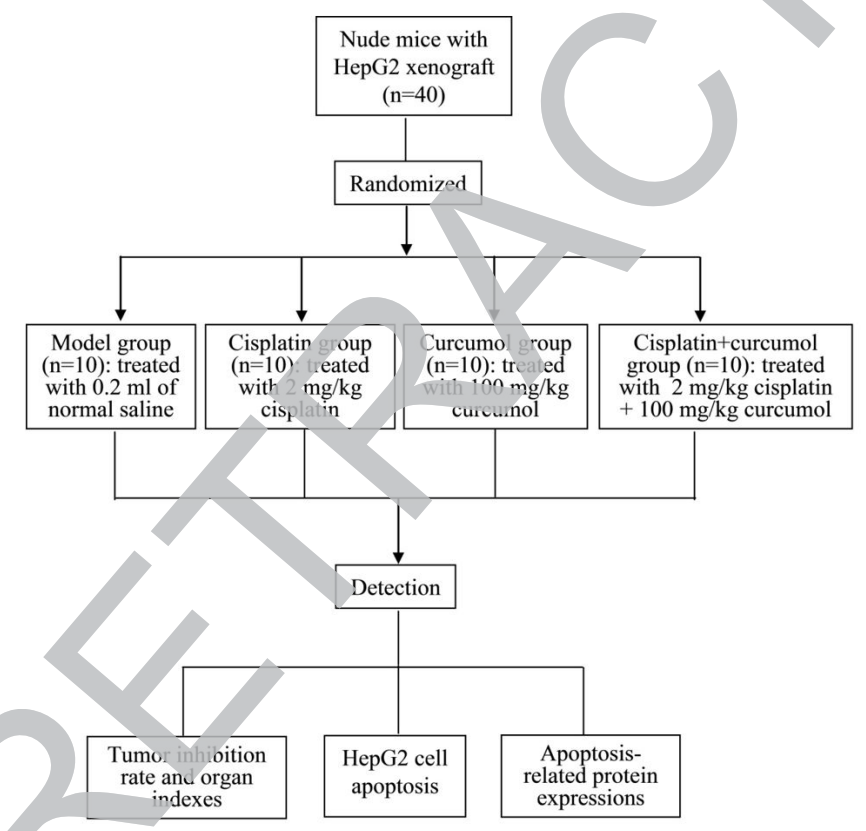

Figure 1. Flow chart of the randomization and treatment of animals (n, number).

\subsection{Measurement of tumor inhibition rate and organ indexes}

On the next day after the last administration, the nude mice in each group were weighed, and then were sacrificed by taling the eyeball blood. The xenograft tumor, thymus and spleen were taken, and were weighed respectively. The tumor inhibition rat thymus index and spleen index were calculated as follows: tum or inhibition rate $(\%)=(1$ - tumor weight in treatment group tumor weight in model group) $\times 100 \%$; thymus index $(\mathrm{mg} / \mathrm{g})$ $=$ thymus weight $/$ body weight; spleen index $(\mathrm{mg} / \mathrm{g})=$ spleen weight / body weight.

\subsection{Detection of HepG2 cell apoptosis}

Partial xenograft tumor tissues were taken, and ground slightly. A small amount of PBS was added to he tissues, followed by slightly shaking. The mi cure was filtered using the 200 -mesh sieve. After centrifuging at $2000 \mathrm{rpm}$ or $10 \mathrm{~min}$, the supernatant was discarded. The precipit ed cells were re-suspended in $300 \mu \mathrm{l}$ of binding buffer $\quad 5 \mu \mathrm{L}$ A nnexin VFITC was added to the cells. After mixing ell, the mixture was incubated at room temperature (keeping aw ay from light) for $15 \mathrm{~min}$. Then, $5 \mu \mathrm{L}$ of propidium iodide staining solution and $200 \mu \mathrm{L}$ of binding buffer were a ded fter nixing well, the mixture was incubated at room temperature for $5 \mathrm{~min}$. Finally, the mixture was loaded on the flow cytometer to detect the apoptosis of HepG2 cells. the apotosis rate was calculated.

\section{Deter ination of apoptosis-related protein expressions}

expressions of apoptosis-related proteins including B-cell lymphoma-2 (Bcl-2), B-cell lymphoma-2 associated X (Bax) and Caspase-3 in xenograft tumor were determined by western blot analysis. Partial xenograft tumor tissues were taken. The total protein samples were prepared using RIPA buffer according to the manufacturer's instructions. The protein concentration was quantified using the BCA method. A $40 \mu \mathrm{g}$ of total protein samples were taken for SDS-PAGE. The separated proteins were transferred to the PVDF membranes, followed by blocking with $5 \%$ skimmed milk powder at room temperature for $2 \mathrm{~h}$. After washing with TBST for 3 times, each time for $5 \mathrm{~min}$, the membranes were incubated with the primary antibody against Bcl-2, Bax and Caspase- 3 overnight at $4{ }^{\circ} \mathrm{C}$, respectively. After washing with TBST for 3 times, each time for $5 \mathrm{~min}$, the membranes were incubated with the horseradish peroxidase-conjugated secondary antibody for $2 \mathrm{~h}$ at room temperature. After washing with TBST for 3 times, each time for $10 \mathrm{~min}$, the gray value of protein bands was analyzed by fluorescence scanning imaging system. $\beta$-actin was used as the internal parameter. The ratio of gray value of target protein band to that of $\beta$-actin band was used as the relative expression level of the target protein.

\subsection{Statistical analysis}

Results were expressed as mean \pm SEM. For comparisons among the different groups, one-way analysis of variance (ANOVA) was used, followed by the Tukey post hoc test. Values of $\mathrm{P}<0.05$ were considered statistically significant. 


\section{Results}

\subsection{Nude mice survival state and xenograft tumor growth}

At the initial stage of treatment, the food intake, water drinking, behavior and mental state of the nude mice had no obvious difference among four groups. With the extension of treatment time, the nude mice in model group gradually showed the slow response, reduced food intake and water drinking, emaciation and rough hair; the xenograft tumor grew rapidly. Compared with the model group, the symptoms of nude mice in cisplatin, curcumol and cisplatin+curcumol groups were significantly mitigated, and the growth of xenograft tumor was slowed. The improvement of nude mice survival state and xenograft tumor growth in cisplatin+curcumol group was the most obvious.

\subsection{Comparison of tumor weight and tumor inhibition rate among four groups}

At the end of treatment, compared with model group, the tumor weight in cisplatin, curcumol and cisplatin+curcumol groups was significantly decreased, respectively $(\mathrm{P}<0.05)$. In addition, there was significant difference of tumor weight among cisplatin, curcumol and cisplatin+curcumol groups $(\mathrm{P}<0.05)$. The tumor inhibition rate in cisplatin, curcumol and cisplatin+curcumol groups was 35.34\%, 25.05\% and 46.29\%, respectively. The tumor inhibition rate in cisplatin+curcumol group was the highest (Table 1).

\subsection{Comparison of thymus index and spleen index among four groups.}

Table 2 showed that, after treatment, the thymus index and spleen index of nude mice in cisplatin group and cisplatin+curcumol group were significantly lower than those in model group, respectively $(\mathrm{P}<0.05)$. There was no significant difference of each index between model group and curcumol group and between cisplatin group and cisplatin+curcumol group, respectively.

\subsection{Comparison of HepG2 cell apoptosis rate among four groups}

At the end of treatment, the apoptosis rate of HepG2 cells in model, cisplatin, curcumol and cisplatin+curcumol groups was $(3.16 \pm 0.45) \%,(32.84 \pm 3.29) \%,(13.14 \pm 2.56) \%$ and $(42.04 \pm$ $4.11) \%$, respectively. The apoptosis rate in cisplatin, curcumol and cisplatin+curcumol groups was significantly higher than that in model group, respectively $(\mathrm{P}<0.05)$. The apoptosis rate in curcumol group was significantly lower than that in cisplatin group $(\mathrm{P}<0.05)$, but the apoptosis index in cisplatin+curcumol group was significantly higher than that in cisplatin group $(\mathrm{P}$ $<0.05$ ) (Figure 2).

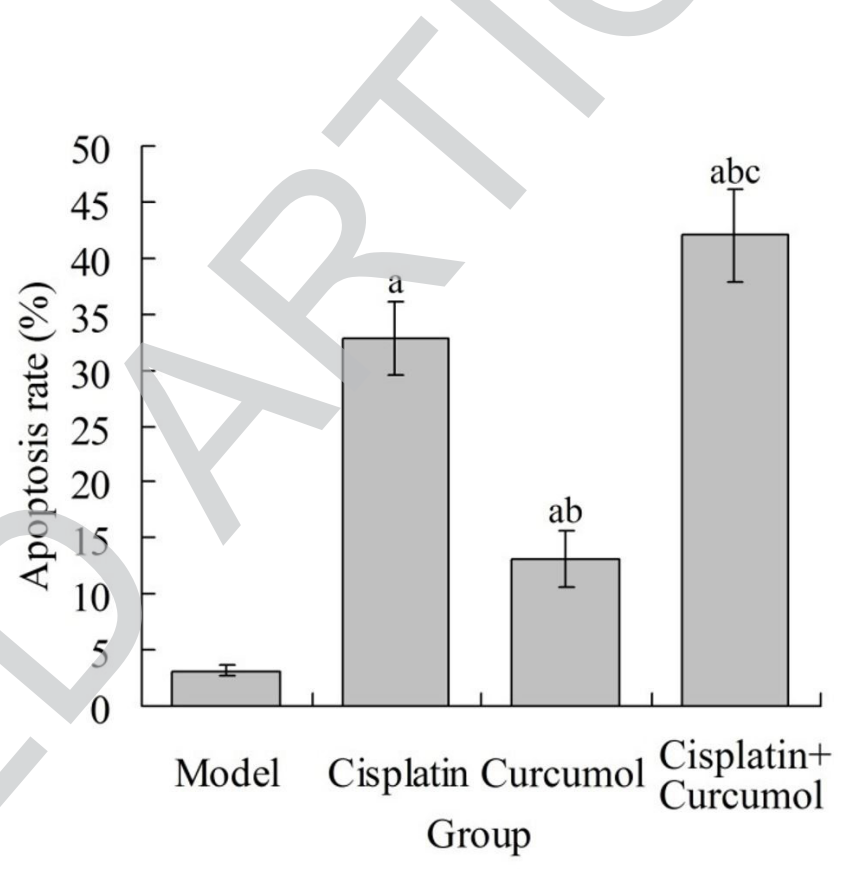

Figure 2. Comparison of HepG2 cell apoptosis rate among four groups $(\mathrm{n}=10) .{ }^{\mathrm{a}} \mathrm{P}<0.05$ compared with model group; ${ }^{\mathrm{b}} \mathrm{P}<0.05$ compared with cisplatin group; ${ }^{\mathrm{P}}<0.05$ compared with curcumol group.

Table 1. Comparison of tumor weight and tumor inhibition rate among four groups.

\begin{tabular}{cccc}
\hline Group & Number & Tumor weight $(\mathrm{g})$ & Tumor inhibition rate (\%) \\
\hline Model & 10 & $1.77 \pm 0.17$ & - \\
Cisplatin & 10 & $1.15 \pm 0.23^{\mathrm{a}}$ & 35.34 \\
Curcumol & 10 & $1.33 \pm 0.12^{\mathrm{ab}}$ & 25.05 \\
Cisplatin+curcumol & 10 & $0.94 \pm 0.14^{\mathrm{abc}}$ & 46.29 \\
\hline
\end{tabular}

${ }^{\text {aP }}<0.05$ compared with model group; ${ }^{b} \mathrm{P}<0.05$ compared with cisplatin group; ${ }^{\mathrm{c}} \mathrm{P}<0.05$ compared with curcumol group.

Table 2. Comparison of thymus index and spleen index among four groups.

\begin{tabular}{|c|c|c|c|}
\hline Group & Number & Thymus index (mg/g) & Spleen index $(\mathrm{mg} / \mathrm{g})$ \\
\hline Model & 10 & $2.16 \pm 0.50$ & $7.56 \pm 1.46$ \\
\hline Cisplatin & 10 & $1.77 \pm 0.26^{\mathrm{a}}$ & $3.11 \pm 0.45^{\mathrm{a}}$ \\
\hline Curcumol & 10 & $2.14 \pm 0.35^{\mathrm{b}}$ & $7.03 \pm 1.12^{b}$ \\
\hline Cisplatin+curcumol & 10 & $1.72 \pm 0.19^{\mathrm{ac}}$ & $3.04 \pm 0.67^{\mathrm{ac}}$ \\
\hline
\end{tabular}

${ }^{a} \mathrm{P}<0.05$ compared with model group; ${ }^{b} \mathrm{P}<0.05$ compared with cisplatin group; ${ }^{\mathrm{c}} \mathrm{P}<0.05$ compared with curcumol group. 


\subsection{Comparison of Caspase-3 protein expression in xenograft tumor among four groups}

As shown in Figure 3, the relative expression levels of Caspase-3 protein in xenograft tumor in model, cisplatin, curcumol and cisplatin+curcumol groups were $0.05 \pm 0.01,0.16 \pm 0.02$, $0.15 \pm 0.02$ and $0.21 \pm 0.01$, respectively. The Caspase- 3 protein level in cisplatin, curcumol and cisplatin+curcumol groups was significantly higher than that in model group, respectively $(\mathrm{P}<$ $0.05)$, and that in cisplatin+curcumol group was significantly higher than that in cisplatin and curcumol groups, respectively $(\mathrm{P}<0.05)$.

\subsection{Comparison of Bcl-2 and Baxprotein expressions in xenograft tumor among four groups}

Table 3 showed that, the relative expression level of Bcl-2 protein in cisplatin, curcumol and cisplatin+curcumol groups was significantly lower than that in model group, respectively $(\mathrm{P}<0.05)$, and the relative expression level of Bax protein in cisplatin, curcumol and cisplatin+curcumol groups was significantly higher than that in model group, respectively $(\mathrm{P}<0.05)$. Compared with cisplatin and curcumol groups, in

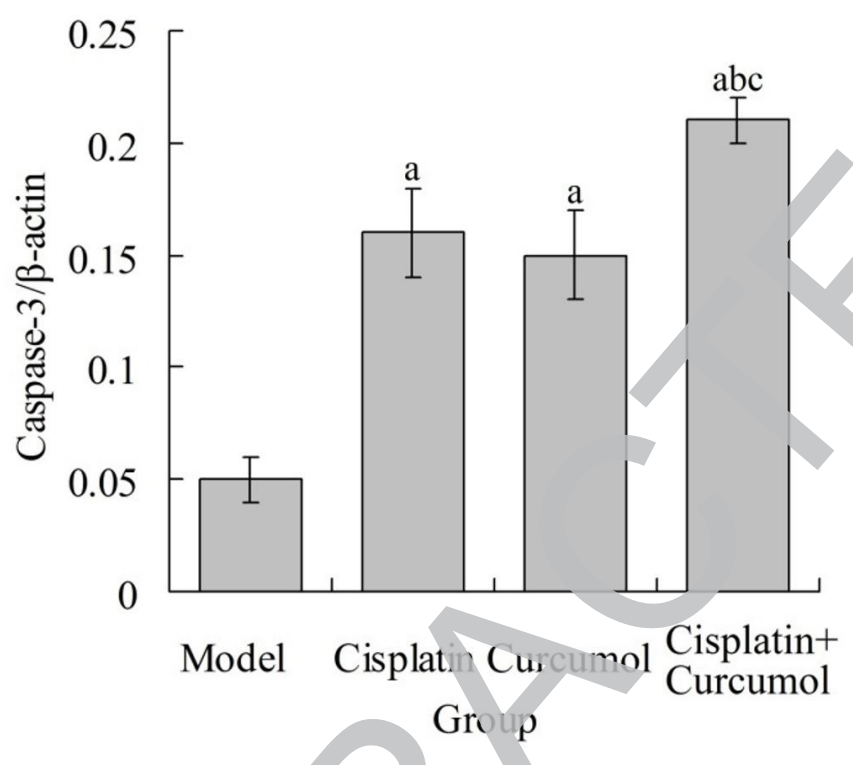

Figure 3. Comparison of Casp $\mathrm{e}-3$ prote $\mathrm{n}$ expression in xenograft tumor among four groups $(n-10) . \mathrm{P}<0.05$ compared with model group; ${ }^{\mathrm{P}}<0.05$ compared th cisplatin group; ${ }^{\mathrm{C}} \mathrm{P}<0.05$ compared with curcumol group. cisplatin+curcumol group the $\mathrm{Bcl}-2$ protein level was significantly decreased, respectively $(\mathrm{P}<0.05)$, and the Bax protein level was significantly increased, respectively $(\mathrm{P}<0.05)$

\section{Discussion}

HCC is a kind of cancer with strong ability of metastasis and invasion of other organs and tissues. Because the onset of HCC is relatively hidden, most patients have missed the opportunity of surgery when they are diagnosed. The 5-vear recurrence rate of HCC is very high (Kaido et al., 2005). Therefore, it is an urgent medical problem to delay the de elopment of HCC and prolong the survival period of patients.

Curcumol is a monomeric compound isolated irom zedoary turmeric oil. The in vitro and animal experiments have shown that curcumol can inhibi the proliferation and growth of lung cancer, gastric cancer, colorectal cancer, breast cancer, nasopharyngeal cancer, and other mor cells. The action mechanism involves the di ect killing of tumor cells, inhibition of nucleic acid metabolism, inhibition of tumor angiogenesis, induction of cell apoptosis, promotion of cell differentiation and many ther aspects (Cai et al., 2017; Huang et al., 2017; Zang et al., 2017, fi et al., 2018). In this study, curcumol was isolated from from zedoary turmeric oil, and the inhibitory effect of curcum ol on growth of human HCC HepG2 xenografts in mude mice was investigated. Results showed that, after two weeks of reatment, the tumor weight and tumor inhibition rate in cisplatin +curcumol group was obviously lower than that in isplatin group, respectively. This indicates that, curcumol can obviously increase the inhibitory effect of cisplatin on growth of HCC HepG2 xenografts in nude mice. In addition, there was no significant difference of thymus index or spleen index between cisplatin group and cisplatin+curcumol group. This suggests that, the use of curcumol cannot increase the toxic and side effects of drugs on the thymus and spleen of animals.

Apoptosis plays an important role in tumor inhibition. Caspase and $\mathrm{Bcl}-2$ gene families play an important role in the process of apoptosis (Monney et al., 1998). Caspase-3 is the key protease to activate the apoptotic protease activating factor-1 (Apaf-1). It is involved in the initiation of apoptosis and the regulation of the whole process of apoptosis (Zou et al., 1997). Bcl-2 can inhibit the rupture of mitochondrion, and directly combine with Apaf-1 to inhibit the activation of Caspase-3 (Marsden et al., 2002). In addition, Bcl-2 can inhibit the cytotoxicity of Bax, regulate the intracellular calcium concentration, thus inhibiting the apoptosis (Wang et al., 2014). Bax is a member of Bcl-2 gene family. It can induce the change of mitochondrial permeability,

Tabl 3. Comparison of Bcl-2 and Bax protein expressions in xenograft tumor among four groups.

\begin{tabular}{|c|c|c|c|}
\hline Group & Number & Bcl- $2 / \beta$-actin & $\mathrm{Bax} / \beta$-actin \\
\hline Model & 10 & $0.63 \pm 0.08$ & $0.28 \pm 0.42$ \\
\hline Cisplatin & 10 & $0.33 \pm 0.04^{\mathrm{a}}$ & $0.83 \pm 0.23^{\mathrm{a}}$ \\
\hline Curcumol & 10 & $0.45 \pm 0.02^{\mathrm{ab}}$ & $0.56 \pm 0.12^{\mathrm{ab}}$ \\
\hline Cisplatin+curcumol & 10 & $0.21 \pm 0.03^{\mathrm{abc}}$ & $1.12 \pm 0.17^{\mathrm{abc}}$ \\
\hline
\end{tabular}

0.05 compared with model group; ${ }^{\mathrm{b}} \mathrm{P}<0.05$ compared with cisplatin group; ${ }^{\mathrm{C}} \mathrm{P}<0.05$ compared with curcumol group. Bcl-2, B-cell lymphoma-2; Bax, B-cell lymphoma-2 associated X. 
release cytochrome $\mathrm{C}$, activate Caspase- 9 , and promote the apoptosis (Jürgensmeier et al., 1998; Sodhi \& Sethi, 2004). In addition, Bax can polymerize with $\mathrm{Bcl}-2$ to form dimer, thus inhibiting the activity of $\mathrm{Bcl}-2$ and promoting the apoptosis (Salakou et al., 2007). In our study, after treatment, compared with model group, in cisplatin+curcumol group the apoptosis rate of HepG2 cells was significantly increased, the expression levels of Caspase- 3 and Bax proteins in xenograft tumor were significantly increased, and the expression level of $\mathrm{Bcl}-2$ protein was significantly decreased. This indicates that, the combined use of cisplatin and curcumol can further promote the apoptosis of tumor by up-regulating the Caspase- 3 and Bax expressions and down-regulate the $\mathrm{Bcl}-2$ expression in tumor tissues.

\section{Conclusion}

In summary, curcumol can obviously increase the inhibitory effect of cisplatin on growth of HCC HepG2 xenografts in nude mice. The mechanism may be related to the enhanced promotion of apoptosis of tumor by up-regulating the Caspase- 3 and Bax expressions and down-regulate the Bcl-2 expression in tumor tissues. In addition, the additional use of curcumol cannot increase the toxic and side effects on thymus and spleen of animals. This study has provided an experimental basis for the clinical application of curcumol to cancer therapy. However, the other action mechanisms of curcumol on the tumor growth still need to be further explored.

\section{Conflict of interest}

The authors declare that there is no conflict of interest.

\section{References}

Cai, F., Chen, M., Zha, D., Zhang, P., Zhang, X., Cao, N., Wang, J., He, Y., Fan, X., Zhang, W., Fu, Z., Lai, Y., Hua, Z. C., \& Zhuang, H. (2017). Curcumol potentiates celecoxib-induced growth inhibition and apoptosis in human non-small cell lung cancer. Oncotarget, 8(70), 115526-115545. http://dx.doi.org/10.18632/oncotarget.23308. PMid:29383179.

Chen, X., Zong, C., Gao, Y., Cai, R., Fang, L., Lu, J., Liu, F., \& Qi, Y. (2014). Curcumol exhibits anti-inflammatory properties by interfering with the JNK-mediated AP-1 pathway in lipopolysaccharide-activated RAW264.7 cells. European Journal of Pharmacology, 723, 339-345. http://dx.doi.org/10.1016/j.ejphar.2013.11.007. PMid:24269960.

Costa, G. L. A., Buccini, D. F., Arruda, A. L. A., Favaro, S. P., \& Moreno, S. E. (2020). Phytochemical profile, anti-inflammatory, antimutagenic and antioxidant properties of Acrocomia aculeata (Jacq.) Lodd. pulp oil. Food Science and Technology, 40(4), 963-971. http://dx.doi. org/10.1590/fst.25319.

Huang, L. Z., Wang, J., Lu, F. T., Yang, F. C., Chen, X., Hong, X., \& Jiang, X. S. (2013). Mechanism study on anti-proliferative effects of curcumol in human hepatocarcinoma HepG2 cells. Zhongguo Zhongyao Zazhi, 38(11), 1812-1815. [in Chinese]. PMid:24010301.

Huang, L., Li, A., Liao, G., Yang, F., Yang, J., Chen, X., \& Jiang, X. (2017). Curcumol triggers apoptosis of p53 mutant triple-negative human breast cancer MDA-MB 231 cells via activation of p73 and PUMA. Oncology Letters, 14(1), 1080-1088. http://dx.doi.org/10.3892/ ol.2017.6273. PMid:28693277.

Huang, T., Yang, X., Ji, J., Wang, Q., Wang, H., \& Dong, Z. (2020). Inhibitory effects of tanshinone IIA from Salvia miltiorrhiza Bge on human bladder cancer BIU-87 cells and xenograft in nude mice. Food Science and Technology, 40(1), 209-214. http://dx.doi. org/10.1590/fst.38818.

Jürgensmeier, J. M., Xie, Z., Deveraux, Q., Ellerby, L., Bredesen, D., \& Reed, J. C. (1998). Bax directly induces release of cytochrome c from isolated mitochondria. Proceedings of the National Academy of Sciences of the United States of America, 95(9), 4997-5002. http:// dx.doi.org/10.1073/pnas.95.9.4997. PMid:9560217.

Kaido, T., Oe, H., Yoshikawa, A., Mori, A., Arii, S., \& Imamura, M. (2005). Tissue factor is a useful prognostic factor of recurrence in hepatocellular carcinoma in 5-year survivors. Hepato-Gastroenterology, 52(65), 1383-1387. PMid:16201079.

Li, X., Liu, H., Wang, J., Qin, J., Bai, Z., Chi, B., Yan, W., \& Chen, X. (2018). Curcumol induces cell cycle arrest and apoptosis by inhibiting IGF-1R/PI3K/Akt signaling pathway in human nasopharyngeal carcinoma CNE-2 cells. Phytotherapy Research, 32(11), 2214-2225. http://dx.doi.org/10.1002/ptr.6158. PMid:30069933.

Liu, H., Wang, J., Tao, Y., Li, X., Qin, J., Bai, Z., Chi, B., Yan, W., \& Chen, X. (2019). Curcumol inhibits colorectal cancer proliferation by targeting miR-21 and modulated PTEN/PI3K/Akt pathways. Life Sciences, 221, 354-361. http://dx.doi.org/10.1016/j.lfs.2019.02.049. PMid:30811964.

Marsden, V. S., O'Connor, L., O’Reilly, L. A., Silke, J., Metcalf, D., Ekert, P. G., Huang, D. C., Cecconi, F., Kuida, K., Tomaselli, K. J., Roy, S., Nicholson, D. W., Vaux, D. L., Bouillet, P., Adams, J. M., \& Strasser, A. (2002). Apoptosis initiated by Bcl-2-regulated caspase activation independently of the cytochrome c/Apaf-1/caspase-9 apoptosome. Nature, 419(6907), 634-637. http://dx.doi.org/10.1038/nature01101. PMid:12374983.

Monney, L., Otter, I., Olivier, R., Ozer, H. L., Haas, A. L., Omura, S., \& Borner, C. (1998). Defects in the ubiquitin pathway induce caspase-independent apoptosis blocked by Bcl-2. The Journal of Biological Chemistry, 273(11), 6121-6131. http://dx.doi.org/10.1074/ jbc.273.11.6121. PMid:9497330.

Rawat, D., Shrivastava, S., Naik, R. A., Chhonker, S. K., Mehrotra, A., \& Koiri, R. K. (2018). An overview of natural plant products in the treatment of hepatocellular carcinoma. Anti-cancer Agents in Medicinal Chemistry, 18(13), 1838-1859. http://dx.doi.org/10.217 4/1871520618666180604085612. PMid:29866017.

Salakou, S., Kardamakis, D., Tsamandas, A. C., Zolota, V., Apostolakis, E., Tzelepi, V., Papathanasopoulos, P., Bonikos, D. S., Papapetropoulos, T., Petsas, T., \& Dougenis, D. (2007). Increased Bax/Bcl-2 ratio up-regulates caspase- 3 and increases apoptosis in the thymus of patients with myasthenia gravis. In Vivo (Athens, Greece), 21(1), 123-132. PMid:17354625.

Santos, L. S., Fernandes, C. C., Santos, L. S., Deus, I. P. B. D., Sousa, T. L. D., \& Miranda, M. L. D. (2021). Ethanolic extract from Capsicum chinense Jacq. ripe fruits: phenolic compounds, antioxidant activity and development of biodegradable films. Food Science and Technology, 41(2), 497-504. http://dx.doi.org/10.1590/fst.08220.

Sodhi, A., \& Sethi, G. (2004). Caspase-9 and Bax/Bcl-2 regulation in ultraviolet B-induced apoptosis of murine peritoneal macrophages. Toxicology Mechanisms and Methods, 14(6), 323-329. http://dx.doi. org/10.1080/15376520490434656. PMid:20021098.

Tang, Q. L., Guo, J. Q., Wang, Q. Y., Lin, H. S., Yang, Z. P., Peng, T., Pan, X. D., Liu, B., Wang, S. J., \& Zang, L. Q. (2015). Curcumol induces apoptosis in SPC-A-1 human lung adenocarcinoma cells and displays anti-neoplastic effects in tumor bearing mice. Asian Pacific Journal of Cancer Prevention, 16(6), 2307-2312. http://dx.doi.org/10.7314/ APJCP.2015.16.6.2307. PMid:25824755. 
Tangkijvanich, P., Anukulkarnkusol, N., Suwangool, P., Lertmaharit, S., Hanvivatvong, O., Kullavanijaya, P., \& Poovorawan, Y. (2000). Clinical characteristics and prognosis of hepatocellular carcinoma: analysis based on serum alpha-fetoprotein levels. Journal of Clinical Gastroenterology, 31(4), 302-308. http://dx.doi.org/10.1097/00004836200012000-00007. PMid:11129271.

Thomas, M. (2009). Molecular targeted therapy for hepatocellular carcinoma. Journal of Gastroenterology, 44(Suppl 19), 136-141. http://dx.doi.org/10.1007/s00535-008-2252-z. PMid:19148808.

Tsai, S., Huang, S., Chyau, C., Tsai, C., Weng, C., \& Mau, J. (2011). Composition and antioxidant properties of essential oils from curcuma rhizome. Asian Journal of Arts and Sciences, 2, 57-66.

Wang, J., Huang, F., Bai, Z., Chi, B., Wu, J., \& Chen, X. (2015). Curcumol inhibits growth and induces apoptosis of colorectal cancer LoVo cell line via IGF-1R and p38 MAPK pathway. International Journal of Molecular Sciences, 16(8), 19851-19867. http://dx.doi.org/10.3390/ ijms160819851. PMid:26307972.

Wang, J., Jia, R., Zhang, Y., Xu, X., Song, X., Zhou, Y., Zhang, H., Ge, S., \& Fan, X. (2014). The role of Bax and Bcl-2 in gemcitabine-mediated cytotoxicity in uveal melanoma cells. Tumour Biology, 35(2), 11691175. http://dx.doi.org/10.1007/s13277-013-1156-6. PMid:24014050.
Wu, X. Z., \& Xie, G. R. (2008). Induced differentiation of hepatocellular carcinoma by natural products. African Journal of Traditional, Complementary, and Alternative Medicines, 5(4), 325-331. PMid:20161953.

You, J., Cui, F. D., Li, Q. P., Han, X., Yu, Y. W., \& Yang, M. S. (2005). A novel formulation design about water-insoluble oily drug: preparation of zedoary turmeric oil microspheres with self-emulsifying abiity and evaluation in rabbits. International Journal of Pharmaceutics, 288(2), 315-323. http://dx.doi.org/10.1016/j.ijpharm 2004.10.005. PMid:15620872.

Zang, S., Tang, Q., Dong, F., Liu, H., Li, L., Guo, F., Pan, X., Lin, H., Zeng, W., Cai, Z., Zhong, Q., Zang, N., \& Zang, L. (2017) Curcumol inhibits the proliferation of gastric adenocarcino ma MC-803 cells via downregulation of IDH1. Oncology Reports, 38(6), 3583-3591. http://dx.doi.org/10.3892/or.2017.6028. PMic. 29039582.

Zou, H., Henzel, W. J., Liu, X., Lutschg A., \& Wang, X. (1997). Apaf-1, a human protein homologous to C. elegans CED-4, participates in cytochrome c-dependent ac vation of caspase-3. Cell, 90(3), 405-413. http://dx.doi.org/0.1016/s0092-8674(00)80501-2. PMid:9267021. 